\title{
Immanuel as die geinkarneerde tora: Funksionele Jesusbenaminge in die Matteusevangelie as vertelling
}

\author{
AG van Aarde
}

\begin{abstract}
Emmanuel as the Torah Incarnate: The names of Jesus in Matthew's story

Two tendencies in traditional titular Christology are indicated as methodologically and theologically inadequate. Alternatively, the more prominent names of Jesus are discussed as means by which the narrator in Matthew's story characterises Jesus as the fulfiller of the law and the prophets. The Matthaean Jesus can as such be depicted as Emmanuel, the Torah Incarnate. The names dealt with are Teacher, Rabbi, Kyrios, Son of David, Prophet, Messiah, King of the Jews, Son of man and Son of God.
\end{abstract}

\section{INLEIDING}

Petersen (1978: 111) het die uitdagende moontlikheid raakgesien om die funksionaliteit van Jesusbenaminge in die evangelies vanuit die vertelkunde te beskryf. Hy self het dit egter nie gedoen nie. In sy artikel het hy die literatuurteorie van Boris Uspenski (1973) bekendgestel en op 'n perikoop in die Markusevangelie toegepas. Die artikel self kan beskou word as baanbrekerswerk ten opsigte van die toepassing van narratologie (die literatuurteorie wat hom met verteltekste besig hou) in evangelienavorsing. Sedertdien het etlike publikasies oor die evangelies as vertellinge in Suid-Afrika en veral in Amerika verskyn. Sover my kennis strek, is die teorie van Uspenski met betrekking tot die funksionaliteit van benaminge in verteltekste nog nêrens in evangelienavorsing aangewend nie. Die studie wat die naaste hieraan kom, is die baie bruikbare hoofstuk III in Dawsey (1983: 81-112) se doktorale proefskrif, getitel The literary function of point of view in controlling confusion and irony in the Gospel of Luke. Kingsbury (1986) se boek, Matthew as story, is een van die nuutste narratologiese studies van die Matteusevangelie. Hoewel Kingsbury (1986: 1-2) in sy inleidende paragraaf na sowel Uspenski as Petersen se betrokke werke verwys, hou 
sy hantering van Jesusbenaminge in hoofstuk 2 en 5 (vgl ook Kingsbury 1984: 1985) nie veel meer in as die resultate wat hy met sy vroeëre redaksie-kritiese werke behaal het nie (kyk veral Kingsbury 1975a en die kritiese opmerkings van Hill $1984 \mathrm{n}$ a v van Kingsbury se artikel wat in 1984 gepubliseer is).

Uspenski (1973: 25-27) het in 'n hoofstuk, getitel 'Naming as a problem of point of view in literature', aangetoon hoe uiters funksioneel benaminge in vertelliteratuur is. Dit is naamlik 'n baie effektiewe fraseologiese middel waarmee 'n verteller idees van homself, oor sy karakters en van karakters oor ander karakters kan kommunikeer. 'n Verteller kan byvoorbeeld by wyse van die aanwending van verskillende benaminge vir één karakter wys op die perspektiewe van die ander karakters wat elkeen (of sommige tesame) onderskeidelik deur middel van ' $n$ tipiese benaming vir die betrokke karakter, ' $n$ bepaalde perspektief ten opsigte van dié karakter (en implisiet van ander karakters) uitdruk (kyk Uspenski 1973: 26). Dit geld veral benaminge wat ten opsigte van die hoofkarakter (protagonis) aangewend word: '. . . the author's attitude toward his hero is manifested primarily in his way of naming the hero ...' (Uspenski 1973: 22).

Dawsey het in sy werk oor die Lukasevangelie bevestig dat Jesusbenaminge nie willekeurig en uitruilbaar deur òf die verteller òf die karakters in die vertelling gebruik word nie. Verskillende karakters en karaktergroepe verwys onderskeidelik na Jesus met verskillende benaminge. Dawsey (1983: 99-102) toon ook aan dat Lukas sy bronne wysig deur bepaalde Jesusbenaminge uit die monoloë en dialoë van sekere karakters en karaktergroepe uit te haal en ander benaminge weer in te voer. So word die Markusevangelie, byvoorbeeld, as een van Lukas se bronne aangepas deur die benaminge 'Leermeester' (didaskale) en Rabbi ( $r a b b i$ ) uit die redes van die binnekring-volgelinge van Jesus te haal em onder andere die benaming 'Meester' (epistáta)* deur hulle te laat gebruik, terwyl 'Leermeester' (didáskale) ingevoer word in die redes van sommige lede van die skare.

In die Matteusevangelie is dit weer opvallend dat die Joodse leiers en ander opponente van Jesus, nooit na Hom met die benaming 'Here' (kúrios), soos die dissipels, verwys nie. Die opponente spreek Jesus aan

* Die Jesusbenaming epistáta kom net in die Lukasevangelie voor en dit is verwarrend dat die Nuwe Afrikaanse Bybelvertaling hierdie benaming net soos kúrios met 'Here' vertaal. 
as 'Leermeester' (didáskale) (o a in Matt 19: 16) of 'Rabbi' (rabbi) (o a in Matt 26: 49). Dit laat die vraag ontstaan na die funksionaliteit van die Jesusbenaminge in die Matteusevangelie as vertelling. Hierdie vraag, dié na die benaminge wat in die evangelies vir Jesus as 'titels' gebruik word, maak gewoonlik die tradisionele objek van ondersoek uit wanneer daar na die Christologie van die onderskeie evangeliste gevra word.

Die bedoeling met hierdie artikel is om eerstens twee tendense in die tradisionele titel-Christologie as metodologies en teologies onbevredigend aan te dui. Tweedens wil ons veral in die artikel aantoon hoe die belangrikste Jesusbenaminge in die Matteusevangelie as vertelling funksioneel bydra om Jesus as die vervuller van die wet en die profete te karakteriseer.

Hierdie bepaalde karakterisering van Jesus is ' $n$ prominente motief in die vertellersperspektief op die ideologiese vlak in die Matteusevangelie. Uspenski se term 'ideologie' het betrekking op die netwerk van idees en temas wat in ' $n$ vertelteks voorkom sodat daar gepraat kan word van 'n vertelling se ideologiese perspektief(we). In 'n nieartistieke teks, soos 'n evangelie, kom daar gewoonlik één dominante ideologiese perspektief voor. Omdat die evangelies religieuse tekste is, is die verteller se ideologiese perspektief in werklikheid sy teologiese perspektief. Die oorheersende teologiese perspektief van die verteller in die Matteusevangelie word fraseologies saamgevat in die konsep Godby-ons. Die Hebraïstiese Jesusbenaming 'Immanuel' (Immanouël) (Matt 1: 23) is ' $n$ direkte eksplikasie op die oppervlak van 'n dieper liggende God-by-ons teologiese perspektief. Alle gebeure, karakters en wat dies meer sy in die Matteusevangelie word konstant vanuit hierdie één spesifieke perspektief aangebied. Dit weerklink in elke episode van die evangelie. Die perspektiewe van waaruit die protagonis en die ander karakters vertel word, asook die besonderhede rakende die topografie en die verskillende tydsvlakke, is daaraan ondergeskik, daarby ineengeskakel en dien as manifestasies daarvan. Dit geld ook die ander benaminge van Jesus wat nie so ekspliserend as 'Immanuel' is nie, asmede die verskillende benaminge van die onderskeie ander karakters.

Dit is juis in hierdie verband dat Uspenski se teorie oor die funksionaliteit van benaminge 'n belangrike bydrae in die studie van die Christologieë van die onderskeie evangelies kan maak. Soos ons hierbo aangedui het, wil ons in die artikel aantoon hoe die belangrikste Jesusbenaminge in die Matteusevangelie fraseologiese manifestasies is 
van die teologiese konsep God-by-ons. Bloot die feit dat die verteller self in ' $n$ profetiese vervullingsitaat Jesus 'Immanuel' noem (Matt 1: 22-23), is aanduiding daarvan dat die verteller sy teologiese perspektief laat saamval met die perspektief van die hoofkarakter. Dit kom daarop neer dat die dominante teologiese perspektief in die Matteusevangelie nie net manifesteer in dit wat Jesus doen, praat, dink ensovoorts en in die wyse waarop hy optree, praat ensovoorts nie, maar ook in die benaminge wat vir Hom gebruik word en funksioneel is met die oog op sy woorde en dade.

Ons het gesê dat ons wil aantoon hoe Jesusbenaminge funksioneel bydra om Jesus as die vervuller van die wet en die profete te karakteriseer en dat hierdie karakterisering ' $n$ prominente motief in Matteus se dominante teologiese perspektief is. Dit is daarom vereers nodig om die verband tussen bogenoemde karakterisering en die teologie van die Matteusevangelie meer toe te lig.

Matteus se 'teologie' bestaan uit die skep van 'n analogie tussen die Jesusgebeure, vanaf geboorte tot opstanding (voor-pase), en die kerk in die tyd vanaf opstanding tot wederkoms (na-pase). Met 'kerk' bedoel ons hier die ruimte waarin onder andere die implisiete leser van die evangelie hom bevind en die implisiete leser van die Matteusevangelie is 'n dissipel-leser (kyk Via 1980: 209-210). Dit kom daarop neer dat die werklike, veronderstelde lesers geassosieer word met die rol van die dissipels in die evangelie. Die 'analogie' in die 'teologie' van Matteus het betrekking op die assosiasie wat Matteus tussen sy lesers en die karakters en gebeure in sy vertelling oor Jesus gesuggereer het. Hierdie assosiasie is veral daarop afgestem om riglyne aan te dui vir die korrekte verhouding wat daar tussen die 'leiers' (die implisiete dissipel-lesers) en die noodlydende 'volk' in die ruimte van die na-pase kerk moet bestaan. Matteus se doel met hierdie assosiasie is verder dat hierdie verhouding moet getuig van die liefde wat Jesus vir die Joodse skare (en die heidene) betoon het. Jesus het dit gedoen deur met goddelike gesag hulle sondes te vergewe en so absoluut gehoorsaam die wil van die Vader, die 'wet en die profete' (= die tora), uitgevoer. Die liefde is die vervulling van die tora en die vervulling van die wil van die Vader is die lewenspraktyk wat toegang verleen tot die koninkryk van die hemel. Hoewel Jesus reeds by die aanvang van sy liefdeswerk onder die Joodse skare (en die heidene) dissipels geroep en hulle 'vissers van mense' gemaak het, begin hulle sending in die wêreld eers nadat Jesus uit die dood opgestaan het. Die dissipels, en so ook die leser van die Matteusevangelie, kry 'n leeropdrag. Hierdie leeropgedrag het as in- 
houd die tora as die wil van God, soos Jesus self as Immanuel dit geïnterpreteer en beliggaam het. Die blywende teenwoordigheid van Jesus as God-by-die-kerk tot aan die einde van die wêreld word sigbaar in die gehoorsaamheid van die dissipels, terwyl hulle besig is met die uitvoering van hulle leeropdrag om ander mense dissipels te maak, om na analogie van Jesus se optrede die wil van God te doen. Indien die dissipels hierdie roeping van hulle insien en uitvoer, het hulle soos 'n skrifgeleerde geword wat 'n leerling in die koninkryk van die hemel geword het. Die dissipels in die Matteusevangelie het egter die geneigdheid om met die legalistiese formalisme van die Joodse skrifgeleerdes en Fariseërs gemene saak te maak.

In vorige artikels is onderskeidelik die funksionaliteit van die wet en die profete (die 'Ou Testament') as 'n tydskategorie in Matteus se teologie (Van Aarde 1985) en die intrige in sy teologie (Van Aarde 1986a) bespreek. In hierdie artikel word die klem gelê op die funksionaliteit van Jesusbenaminge in Matteus se teologie. Die studie bevestig Gibbs (1968) se verwysing na die Matteaanse Jesus as die 'Torah Incarnate' en ook die volgende opmerking van Hummel (1966: 56) oor die Matteusevangelie: 'Christologie und Tora werden unlöslich miteinander verknüpft.'

\section{PROFESSOR CH RAUTENBACH}

Hierdie studie met die hooftitel, 'Immanuel as die geïnkarneerde tora', word opgedra aan prof $\mathrm{CH}$ Rautenbach, rektor-emeritus van ons alma mater, die Universiteit van Pretoria.

Waar die term 'tora' genoem word, daar word die term 'skrifgeleerde' veronderstel. Volgens Matteus moet ons nie aanneem dat ' $n$ skrifgeleerde nie 'n Christen kan wees nie. Inteendeel, Matteus lewer 'n uitspraak van Jesus oor waarin daar verwys word na 'n skrifgeleerde wat 'n leerling in die koninkryk van die hemel geword het (Matt 13: 52). Hoh (1926) het in hierdie verband van 'der christliche grammateus' gepraat. Hierdie 'Christenskrifgeleerde' word deur Matteus uitgebeeld as die vader van die huis wat met ou en nuwe inhoude onderrig gee. So 'n skrifgeleerde is met ander woorde ook 'n leerling - die lewenslange student - wat van die 'oue' in die lig van die 'nuwe' kennis neem, dit sy eie maak en dit verder uitdra. Vir Matteus beteken dit dat daar kennis geneem word van en onderrig gegee word oor die ou tora in die lig van die nuwe gebeure rondom Jesus, die 'geïnkarneerde tora'.

Gnilka maak die volgende toepassing na aanleiding van Matteus 13: 
52 en ons maak dit van toepassing op prof $\mathrm{CH}$ Rautenbach wat steeds op vyf-en-tagtigjarige ouderdom die verpersoonliking van die ideale Christenskrifgeleerde èn Christenleerling is:

Der Christ bleibt zeit seines Lebens Jünger, Schüler. Das Examen steht noch bevor. Im Bild vom Hausvater sind jene besonders angesprochen, die in der Verkündigung und Katechese tätig sind. Neues und Altes sollen sie austeilen (Gnilka 1986: 512).

\section{TRADISIONELE TITEL-CHRISTOLOGIE}

Ons het gesê dat die benaminge wat in die evangelies vir Jesus as 'titels' gebruik word, die tradisionele objek van ondersoek uitmaak wanneer daar na die Christologie (Jesusbeeld) van die onderskeie evangeliste gevra word. Twee tendense in hierdie ondersoek moet egter enersyds as metodologies en andersyds as teologies onbevredigend aangestip word.

\subsection{Die histories-kritiese metode is agtergehaal}

Eerstens is dit metodologies agtergehaal om te meen dat ' $n$ studie van geïsoleerde Christologiese titels wat vanuit ' $n$ histories-kritiese hoek gemaak word, die mees suksesvolle invalshoek vir die ondersoek na die onderskeie Jesusbeelde in die evangelies sou wees. Die historieskritiese ondersoek het aanvanklik die klem geplaas op die herkoms van die Christologiese titels in df die Palestynse òf die Hellenistiese bodem, en op die oorleweringsgeskiedenis van die titels vanaf die historiese Jesus deur die tradisielae van die Palestyns-Joodse Christendom en die Hellenisties-Joodse Christendom heen tot dié van die Hellenistiesheidense Christendom. Hahn (1974) se wydgelese proefskrif, Christologische Hoheitstitel: Ihre Geschichte im frühen Christentum, is 'n uitstaande voorbeeld van so 'n histories-kritiese ondersoek. Sy studie is gemaak vanuit ' $n$ tradisie-kritiese hoek en die boek is deur baie gesien as ' $n$ welkome standaardwerk oor die Christologie van die Nuwe Testament wat dié van Cullman (1966), Die Christologie des Neuen Testaments, vervang het.

Ondersoekers wat hulle met die eksegetiese metodologie besig hou, het daarop begin wys dat die histories-kritiese benadering, soos onder andere die tradisie-kritiek, net tot die herkenning van die historiese wording van tekste kan bydra. Kealy (1979: 167) het gesê: Too often it 
seemed to be as if the genuine gospel lay somewhere behind the present gospels.' Hoewel iemand soos Hahn (1974: 9) destyds wel 'n aanvoeling vir die hermeneutiese belang van die 'evangelie as geheel' gehad het, is dit egter nie deur hom in sy beskrywing van die Christologie van die onderskeie evangeliste benut nie.

Die redaksie-kritiek het as 'n ander histories-kritiese metode hierop verbeter. Hierdie metode het vir die eerste keer eksplisiet met die evangelie as eenheid erns gemaak. Wat vir die studie van die Christologie van die onderskeie evangeliste in hierdie verband van belang is, is die feit dat die redaksie-kritiek met die teologiese profiel van 'n individuele evangelis as redaktor ('schriftstellerische Einzelpersönlichkeit' - Rohde 1966) rekening hou. Dit sou ook nie 'n oordrywing wees om te beweer dat die meeste vermeldenswaardige navorsingsartikels oor die evangelies wat gedurende die sewentigerjare gepubliseer is, redaksie-kritiese studies was nie. In 1975 het Harrington die eerste dekade van redaksie-kritiese Matteusstudies oorsigtelik saamgevat. Volgens Harrington (1975: 388) het daar op daardie stadium 'n aanvoeling in Matteusnavorsing bestaan dat ' $n$ omvattende beskrywing van Matteus se Christologie vanuit 'n redaksie-kritiese hoek nodig geword het.

Kingsbury het probeer om met die verskyning van sy boek, Matthew: Structure, christology, kingdom, in 1975 dié leemte te vul. Norman Perrin het op die stofomslag van Kingsbury se werk beweer dat dit enersyds die belangrikste boek tot op hede (1975) is met betrekking tot die metode van interpretasie van die Matteusevangelie en andersyds die nuwe beginpunt is vir navorsers van toekomstige Matteusstudies. Sedertdien het Kingsbury sowel voorwaardelike navolging (kyk o a Nolan 1979 en Meier 1979) as skerp kritiek (kyk o a Barr 1976: 351; Borsch 1977; Keck 1980; Hill 1980a en Tatum 1981) ondervind. Maar ook die redaksie-kritiek het tekortgeskiet in die poging om die holistiese konteks èn die literêre aard van die evangelies toereikend genoeg in ag te neem.

En as daar wel op 'n sekere hoogte daarin geslaag kan word om met 'n bepaalde eksegetiese metode sowel die literêre karakter as die holistiese konteks van ' $n$ evangelie te verdiskonteer, wat verander dit aan die tradisionele metode dat ' $n$ evangelis se Jesusbeeld beskryf word in terme van die voorkoms van Christologiese titels in die betrokke evangelie? Per slot van sake is die kernprobleem in die tradisionele titel-Christologie die vraag na die kontinuiteit al dan nie van die gebruik van 'n titel deur die historiese Jesus en deur die na-pase 
gemeente (vgl Balz 1967: 17). Reeds die redaksie-kritiek was as sodanig nie meer in hierdie vraagstuk geïnteresseerd nie, maar het die klem laat val op die teologiese profiel van ' $n$ evangelis as uitdrukker van die geloof van 'n spesifieke na-pase gemeentekring. Hierdie benadering was egter steeds geïnteresseerd in die geskiedenis van die vroeë Christendom as sodanig. Die narratiewe karakter van die evangelies is nog nie in berekening gebring nie.

Teen die agtergrond van 'n eksegetiese benadering wat erns maak met die vertelkarakter van die evangelies, is die volgende opmerking van iemand soos Kelber oor die tekortkoming van die historiese kritiek van belang:

It is hard to see any imperative reason why a gospel christology ought to be predicted solely on its author's use of christological titles. In the light of redaction criticism titular christology betrays an arbitrary quality because it pays no attention to the narrative mainstream, the very thoughtway of a gospel. As for a gospel theology, finally, we must withhold credence unless it does justice to the literary, religious structure of the whole and to all the elements which compose it (Kelber 1979: 15).

Ons gaan in hierdie studie nie in op die meriete van die stelling dat die hoofaangeleentheid in die tradisionele titel-Christologie die kontinuïteit al dan nie tussen die gebruik van 'n titel op die voor-pase situasie en die na-pase situasie is nie. Op sigself is die beredenering van hierdie stelling baie belangrik en baie interessant. In die studie van die geskiedenis van Jesus is dit ons insiens inderdaad een van die kernvraagstukke. Wat ons egter nou in die oog het, is om die aangehaalde opmerking van Kelber hierbo te bevestig. Ons het probeer aandui dat dit nie net ' $n$ tradisie-kritiese ondersoek van iemand soos Hahn was wat ontoereikend is om sowel die holistiese konteks as die literêre aard van die evangelies te verdiskonter by die ondersoek na die Christologie van 'n evangelis nie. Ook die redaksie-kritiese werk van iemand soos Kingsbury skiet te kort.

Vandag word Matteus se Jesusbeeld metodologies anders deur Kingsbury bestudeer as voorheen. Soos party ander evangelienavorsers maak hy erns met die literêre karakter van 'n evangelie as vertelling en neem hy Jesus waar as deel van die verteller se karakterbeelding. In die inleiding van die onderhawige artikel het ons reeds daarop gewys dat Kingsbury in sy nuutste boek oor Matteus (en ook geen ander Matteusnavorser, sover ons kennis strek) nie soseer ingegaan het op benaming 
as verteltegniek nie. Ons meen dat dit hierdie aspek van die vertelkunde is wat maak dat die Jesusbeeld in ander terme as dié in die tradisionele titel-Christologie beskryf kan word. Dit bring ons vervolgens uit by ' $n$ ander tekortkoming in die tradisionele titel-Christologie, naamlik die feit dat die rol van Christologiese titels in die evangelies oorskat kan word.

\subsection{Christologiese titels word oorskat}

Die voorwaardelike navolging van èn kritiek op Kingsbury se redaksiekritiese ondersoek na Matteus se Christologie, waarna ons hierbo verwys het, het betrekking op veral Kingsbury se opvatting dat Matteus die skopus van sy teologie saamgevat het in één Christologiese titel ('Seun van God') wat soos 'n brandglas al die strale in een brandpunt opvang. Hy is egter nie die eerste ondersoeker wat van mening was dat Matteus ('n) sekere titel(s) as die dominante titel(s) beskou het nie. Daar was in der waarheid, vóór en ná Kingsbury, verskeie en uiteenlopende standpunte in hierdie verband.

Die volgende onderskeie titel(s) is in die sestiger- en sewentigerjare as die sogenaamde dominante Christologiese titel(s) in Matteus se teologie gereken: 'Seun van Dawid' ten opsigte van die 'aardse' Jesus in die voor-pase-periode èn 'Here' (kúrios) opsigte van die 'opgestane' Jesus in die na-pase (eskatologiese)-periode (Strecker 1966: 118-120, 123-126); Kúrios (Trilling 1964: 21-51; Frankemölle 1974: 80, 85, 89, 144, 298, 377); 'Seun van die mens' (Blair 1960: 83; Lange 1973: 238-241, 245-246, 487-498); Kúrios én 'Seun van die mens' (Davies 1966: 96-99); 'Messias' (Gaston 1975); 'Koning van die Jode' (Schniewind 1968: 1); 'Seun van God' (Kingsbury 1975a: 40-83 en 1977: 34-53) en 'Seun van God' èn 'Kneg' (Gerhardsson 1973). Die 'dominante' titel(s) funksioneer volgens hierdie navorsers of inhoudelik inklusief deurdat dit al die ander titels in die Matteusevangelie sou omvat (vgl bv die 'Seun van God'-titel by Kingsbury, of die 'Kneg'-titel by Gerhardsson) òf kontingent deurdat al die ander titels hulle selfstandigheid behou, maar as auxiliary titles resessief die dominante een onderbou (vgl bv die resessiewe funksionaliteit van die 'Seun van die mens'-titel ten opsigte van die 'aardse' 'Messias'-titel by Walker 1967: 128-132; dié van die Kúrios-titel ten opsigte van die 'Seun van God'-titel by Kingsbury 1975a: 103-113; dié van die 'Messias'-titel en 'Seun van God'-titel ten opsigte van 'Seun van Dawid' = 'Koning'-titel by Nolan 1979: 149, 216-221, 244; en die ellips-voorstelling van Meier 1979: 118 waarvol- 
gens die 'Seun van God'-titel en die 'Seun van die mens'-titel resessief ten opsigte van die 'Seun'-titel funksioneer).

Deesdae klink al hoe meer stemme in die Matteusnavorsing op wat waarsku teen 'n oorbeklemtoning van Christologiese titels en veral teen die soeke na dié sogenaamde 'sentrale' titel in die teologie van die evangelis. Die volgende opmerkings van onderskeidelik Keck (as kritiek op Kingsbury en op die ellips-voorstelling van Meier) en Hill (as kritiek op Kingsbury en op Nolan) is daarom van belang:

... concentrating on christological titles actually misses much of what the New Testament, and the early Christians as well, wanted to say about Jesus ... The same is true for the Gospel according to Matthew. This Gospel includes a great many titles, like Emmanuel, Son of David, Son of God, Son of Man, Christ. Yet Matthew is not as concerned to show how these titles are related to each other as are modern scholars (Keck 1980: 9).

But like most of these who pursue, with enthusiasm and singlemindedness, the search for one over-arching christological theme ... he (BM Nolan - AG v A) underrates other motifs and has to press some material to fit his predetermined mould (Hill 1980b: 68).

Keck se opmerking is behartenswaardig. lemand soos Kingsbury behoort daarvan kennis te neem dat Matteus klaarblyklik nie daarin geïnteresseerd was om 'n struktuur van interrelasionele titels aan sy lesers mee te deel nie. Hierdie kritiek is steeds geldig, selfs nadat Kingsbury sy jongste boek in 1986 uitgegee het. Dit is nie soseer die onderlinge interrelasie van titels wat by die lees van die Matteusevangelie opval nie. As die literêre konteks van die evangelie as geheel en die ontstaanstyd daarvan in die na-pase situasie op Siriese bodem ná die val van Jerusalem in $70 \mathrm{nC}$ in ag geneem word, word raakgesien dat die Jesusbenaminge in die evangelie wel funksioneel is. Die funksionaliteit van die benaminge lê egter nie in 'n uitgewerkte sistematiese interrelasie ten opsigte van mekaar nie. Die Jesusbenaminge word deur die evangelis aangewend om die konflik tussen die voor-pase Jesus en die voor-pase Joodse leiers as transparant van die breuk tussen die na-pase Siriese kerk en die herorganiseerde Jodedom na $79 \mathrm{nC}$ te laat dien. Funksioneel in terme van hierdie getranspareerde konflik, is die Jesusbenaminge in die Matteusevangelie deel van die fraseologiese uitdrukkinge van die karakterisering van Jesus as die vervuller van die 
wet en die profete. Ons sal hierdie tese in afdeling 4 van die artikel uitwerk.

Die opmerking hierbo wat Hill in 1980 gemaak het, is ook vandag na sewe jaar nog steeds van toepassing op Kingsbury. Hill het in 1984 skerp kritiek uitgespreek op 'n artikel waarin Kingsbury (1984) na aanleiding van die vertelkunde Matteus se Jesusbeeld beskryf het. Kingsbury het in hierdie artikel interessante sake in verband met God as karakter in die evangelie aangedui en ons sal nie Hill se kritiek hierop in alle opsigte kan toegee nie. Dit is egter ten opsigte van die Matteaanse Jesus self dat Kingsbury feitlik met geen nuwe inligting vorendag gekom het nie. Hill (1984: 40) sê onder andere: 'It looks as if Kingsbury's language is chosen and calculated to advance his known position' (my beklemtoning).

Een van die bekendste aspekte van Kingsbury se staanplek met betrekking tot die Matteaanse Jesus, is dat die Seun van God-titel die sentrale Christologiese titel in die evangelie is. Heelwat argumente kan hierteen ingebring word (kyk later afdeling 4.3.1). Meier (1979: 218219) vat sy besware soos volg saam:

What the data impose upon us is the abandonment of talk about the central title in Matthew's gospel, along with the implicit image of a circle with one center ... We can certainly say that Matthew's dominant Christology is a Son-Christology. But that should not be automatically equated with a Son-of-God Christology. Matthew's position is broader and more complex than that (beklemtoning deur Meier).

Tog het Meier hiermee in werklikheid net 'n variasie op Kingsbury voorgestel. Matteus se Jesusbeeld kan volgens hom in terme van 'n ellips beskryf word. Die titels 'Seun van God' en 'Seun van die mens' is die twee fokuspunte van die ellips, terwyl die titel 'die Seun' êrens tussenin rondbeweeg. Later sal ons betoog dat die seunskap-motief baie belangrik in die Matteusevangelie is, maar ons kom nie daarby verby dat Keck sy kritiek op Kingsbury met reg ook op Meier van toepassing gemaak het nie. Ons het inderdaad met die ontwerp van 'n oorspanne sisteem van interrelasionele Christologiese titels te doen wat nie in Matteus se teologiese perspektief op die voorgrond is nie.

Maak ons ons nie ook skuldig aan 'n 'single-mindedness' en 'n 'search for one over-arching christological theme' (kyk Hill hierbo) deur te meen dat die Immanuel-benaming die dominante perspektief van Matteus se teologie is nie (kyk veral Van Aarde 1982). Nee. Die verskil 
is dat ons nie van mening is dat die Immanuel-benaming as ' $n$ inklusiewe titel funksioneer deurdat dit al die ander Christologiese titels sou omvat nie. Ons betoog ook nie dat die Immanuel-benaming as die sentrum van 'n ellips funksioneer waarby al die ander titels resessief inskakel nie. Immanuel is as ' $n$ Hebraïstiese benaming 'n direkte eksplikasie van 'n Ou-Testamentiese motief. Dit is hierdie $\mathrm{Ou}$-Testamentiese God-by-ons tematiek wat deur Matteus opgeneem is om die dieper liggende teologiese perspektief uit te maak van waaruit die verteller al die Jesusbenaminge, en alles verder in die Matteusevangelie, evalueer en aanbied. Die Matteaanse Jesus is breedweg in die lig hiervan voorgestel as die vervuller van die Ou Testament, oftewel Immanuel - die geïnkarneerde tora.

\section{JESUSBENAMINGE IN DIE MATTEUSEVANGELIE}

Die Ou Testament in sy destydse omvang is deur Matteus en sy gemeente geken as die 'wet en die profete'. In die Matteusevangelie is daar nie 'n kwalitatiewe onderskeid tussen 'wet' enersyds en 'profete' andersyds nie. Die rede waarom die so genoemde vervullingsitate net uit die 'profete' kom en in die lydensvertelling afwesig is, moet miskien gesoek word in die opvatting wat Matteus waarskynlik gehuldig het, naamlik dat profesieë voorspellings is en dat Jesus dit gehoorsaam tot die dood toe vervul het.

... the expression 'the law and the prophets' denotes quite simply the whole of the OT as it is known to the church of Matthew and functions for it as Scripture (cf $5: 17 ; 7: 12 ; 11: 13 ; 22: 40$ ) (Kingsbury 1977: 82).

Ons gaan vervolgens aan die hand van Jesusbenaminge aantoon waarom die Matteaanse Jesus getipeer kan word as die vervuller van die wet en die profete. Bovermelde metodologiese beswaar teen 'n historiese benadering en die teologiese beswaar teen 'n oorbeklemtoning van Christologiese titels het gevolglik nie daartoe gelei dat ons die besondere belang van benaminge in vertelmateriaal onderskat nie. Hoewel ons Meier (1979: 217) toegee dat Matteus 'is quite capable of making important Christological statements without titles', bly benaming as ' $n$ fraseologiese verteltegniek ' $n$ belangrike hulpmiddel vir die verteller waarmee hy karaktertekening en stemmingsbewegings soos ironie onderneem. 
So gaan ons in die studie aandui dat die benaming 'Leermeester' (didáskalos of rabbi) in die mond van Jesus se teëstanders ironies verwys na Jesus se korrekte interpretasie van die wet en die profete. Die benaming 'Here' (kúrios), aan die ander kant in die mond van die dissipels en die potensiële navolgers van Jesus, verwys op sy beurt na die gesag waarmee Jesus die wet en die profete interpreteer. Die benaming 'Seun van Dawid' (huids David), in die mond van die Joodse skare en heidene, beklemtoon enersyds Jesus se konkrete vervulling van die wet en die profete by wyse van genesings (veral 'blindes' wat begin 'sien') en andersyds Jesus se optrede as die kontinuering van die wet en die profete. Hierdie kontinuïteits-motief, onder andere, is ook aanwesig in die benaminge 'Profeet' (profētēs), 'Messias' (chrístos) en 'Koning' (basileùs). Die benaming 'Seun van die mens' (huids tô̂ anthrōpoû), in die mond van Jesus self, verwys na sy funksie as regter wat by die wederkoms oordeel, met as maatstaf die doen of nie van die wet en die profete. Die benaming 'Seun van God' (huids tôे theô), in die mond van goddelik of demonies geïnspireerde karakters, openbaar Jesus enersyds as dié een wat sy herkoms uit die Vader in die hemel het en andersyds as die absolute gehoorsame Seun wat tot die dood toe elke jota en titteltjie van die wet en die profete vervul het.

\section{1 'Leermeester' en 'Here'}

\subsubsection{Inleiding}

Dit is opvallend dat, terwyl die groepsbenaming 'dissipels' (mathētai) met die benaming 'Leermeester' korreleer (vgl Matt 10: 24), 'Leermeester' of 'Rabbi' nie in die mond van die dissipels met verwysing na Jesus in die Matteusevangelie voorkom nie. Die verhouding tussen ' $n$ dissipel en Jesus word in dié evangelie deur die benaming 'Here' (kúrios) uitgedruk (vgl Bornkamm 1961: 38). Waar die Joodse leiers en Judas Iskariot na Jesus met die benaming didáskalos of rabbi (vgl Matt 9: 11; 17: 24) verwys, daar verwys die dissipels na Hom as kúrios (vgl Matt 14: 28; 17: 4). Hierdie onderskeie twee benaminge vir Jesus, in respektiewelik die mond van sy 'opponente' en sy 'helpers', is veral in die gedeelte oor die pasgamaaltyd (Matt 26: 17-25) opvallend. In hierdie gedeelte spreek Judas Iskariot Jesus aan as rabbi (Matt 26: 25; vgl ook 26: 49), terwyl die ander dissipels Hom aanspreek as kúrios (Matt 26: 22). Hierdie onderskeiding is des te meer opvallend wanneer gelet word op die feit dat daar in die Markus- en Lukasevangelies nie ' $n$ sodanige parallelisme met betrekking tot hierdie benaminge voorkom nie. In 
sowel die Markusevangelie (vgl Mark 4: 38; 9: 5, 38; 10: 35; 13:1) as die Lukasevangelie (vgl Luk 21: 7) kom die vokatief didáskale of rabbi met verwysing na Jesus wel in die mond van die dissipels voor. Matteus het aan die ander kant dié benaming, in die mond van die dissipels, na kúrie verander (vgl Matt 8: 25 met Mark 4: 38; Matt 17: 4 met Mark 9: 5; Matt 20: 33 met Mark 10: 51; rabbi in Mark 11: 21 is deur Matteus weggelaat). Hoewel Jesus in die Matteusevangelie die benaming ho didáskalos met betrekking tot Homself gebruik (Matt 23: 8; 26: 18), kom dit nie in die mond van die dissipels voor nie. Die benaminge 'Leermeester' en 'Here' blyk dus vir die verteller in die Matteusevangelie 'draers' van bepaalde perspektiewe te wees. Dit is duidelik dat daar met behulp van die onderskeie benaminge kúrios en didáskalos sekere aspekte uitgedruk word van die binêre verhoudinge tussen die vertelde karakters: enersyds die verhouding tussen die dissipels as die 'helpers' en die Joodse leiers as die 'antagoniste' met betrekking tot Jesus as die 'protagonis'; andersyds die verhouding tussen Jesus en die Joodse leiers en tussen Jesus en die dissipels.

\subsubsection{Didáskalos}

Die verband waarin die aanspreekvorm didáskale in die mond van die Joodse leiers voorkom, is die so genoemde 'strydgesprekke' tussen Jesus en die Joodse leiers. Hierdie strydgesprekke in die evangelies sentreer, in die algemeen gesien, rondom die tipiese rabbynse kwessie in verband met die korrekte interpretasie van die tora. Die opposisie tussen die protagonis en die antagoniste in die Matteusvertelling het juis, breedweg gesien, betrekking op hierdie problematiek. Hummel (1966: 34,56) verwys soos volg na hierdie aangeleentheid:

In der Auseinandersetzung des Matthäus mit dem Judentum nimmt das Problem des Gesetzes den breitesten Raum ein .... Christologie und Tora werden unlöslich miteinander verknüpft. Die Messianität Jesu wird in ihrer vom jüdischen Messiasbild unterschiedenen Eigenart durch die Tora legitimiert, die Tora umgekehrt durch die messianische Vollmacht Jesus eschatologisch in Geltung gesetzt.

Die funksie van die benaming didáskalos vir Jesus in die mond van die Joodse leiers is om die aard van die opposisie wat daar tussen dié twee partye bestaan, te onderstreep, naamlik dat dit oor die interpretasie van die tora gaan. Dit geld vir al die gevalle waar dié benaming in die 'strydgesprekke' voorkom. 


\subsubsection{Matteus 9: $1-13$}

In Matteus 9: 1-13 (kyk vs 11) gaan dit om Jesus se saameet met tollenaars en sondaars (die non-accounts in die oë van die Joodse leiers) en om die onderrig van Jesus: '. . gaan leer wat dit beteken: "Ek wil barmhartigheid hê en nie offerande nie"' ('n sitaat uit Hos 6: 6). In Jesus se motivering van hierdie logion (vgl die gàr in vs 13) vind ons 'n verwysing na dit wat ons die raison d'être in die intrige van die Matteusevangelie kan noem: '. . want Ek het nie gekom om (sogenaamde $-\mathrm{AG} \vee \mathrm{A}$ ) regverdiges te roep nie, maar sondaars.'

\subsubsection{Matteus 12: 38-42}

Matteus 12: 38-42 (kyk vs 38) handel oor Jesus se versoeking deur die Joodse leiers dat Hy'n teken (uit die hemel/van God - vgl Matt 16: 1-4) vir hulle sal gee. Hierdie 'versoek' moet verstaan word in die lig van die totale Beëlsebul-kontrovers in Matteus 12: 22-50 (vgl Cope 1967: 36-52). In hierdie kontrovers word die Joodse leiers gekontrasteer met die heidene wat positief op Jesus se boodskap reageer. Die oordeel word oor die Joodse leiers aangekondig omdat hulle godslasterende woorde teen die Heilige Gees spreek (vss 22-32). Hierdie skuld van die Joodse leiers word deur die metafoor 'goeie boom'-'goeie vrugte'/ 'slegte boom'-'slegte vrugte' (vs 33) uitgebeeld. 'Goeie vrugte' is om die wil van die Vader in die hemel te doen; 'slegte vrugte' is om blasfêmía te pleeg (vss 46-50). Die konsep 'onvergeeflike sonde' (vss 31-32) figureer in die rabbynse teologie binne die verwysingsraamwerk van die oortreding van die tora as die wil van die Vader (vgl Meier 1980: 135). Volgens Wrege (1978: 134) het die uitdrukking 'sonde teen die Heilige Gees' betrekking op die Joodse leiers se verhindering van die Jesus- en die dissipelsending. In die argument word die 'teken van Jona' gebruik as 'n verwysing na die positiewe reaksie van die heidense Nineviete en die 'teken van Salomo' as 'n verwysing na die positiewe reaksie van die heidense 'koningin van die Suide'. Hierdie verwysinge is voorbeelde van ' $n$ tipiese rabbynse midrash-interpretasietegniek. Die reaksie van die heidene word geteken as dié teenoor die reaksie van die Joodse leiers wat weier om ag te gee op die proklamasie van die wil van God deur Jesus, terwyl Jesus, as God-by-ons, méér is (pleîn ... hōde) as Jona (vs 41) en Salomo (vs 42). Die hele kontrovers gaan dus oor die kwessie van die regte interpretasie van die wet en die profete. Gundry (1982: 242) formuleer dit soos volg: '. . . Jesus' reply deals with the OT, their (die Joodse leiers - AG v A) field of expertise.' 


\subsubsection{Matteus 17: 24-27}

Die strekking van Matteus 17: 24-27 (kyk vs 24), die perikoop wat handel oor Jesus en Petrus se betaling van die tempelbelasting, het basies te doen met die opposisie tussen die dissipels en die Joodse leiers oor Jesus se standpunt met betrekking tot die tempel (kyk Van Aarde 1982b). Die tema 'tempel' in die Matteusevangelie is, vanuit 'n bepaalde hoek bekyk, 'n variasie op die tema 'tora'. Hierdie perikoop kan daarom beskou word as ' $n$ korrelerende parallel met dié in Matteus 12: 1-8 wat handel, in verband met die opposisie tussen Jesus en die Joodse leiers, oor die dissipels se optrede op die sabbatdag. In beide perikope gaan dit om Jesus se 'wets'-interpretasie waardeur formalisme uitgeskakel word (vgl Montefiore 1964/5: 71), terwyl die wet as uitdrukking van die wil van God tog voluit nagekom word.

\subsubsection{Matteus 19: $16-30$}

Matteus 19: $16-30$ (kyk vs 16) is insgelyks 'n passasie met as tema Jesus se (geradikaliseerde) interpretasie van die wet wat skerp kontrasteer met dié van die 'ryk jongman' uit die geledere van die Joodse leiers. Jesus se 'radikale' interpretasie van die tora word gelykgestel met die opdrag om 'volmaak' te wees en hierdie eis het in die verband van die onderhawige perikoop betrekking op die tema 'baie wat eerste is, sal laaste wees, en wat laaste is, eerste' (vs 30 ). Die eis wat in hierdie logion geleë is, is die aflê van die legalisme en formalisme wat die Judaïsme kenmerk. Net soos in Matteus 5: 48 waar die woord téleios (om 'volmaak' te wees) nog 'n keer in die Matteusevangelie voorkom, het ons hier in Matteus 19: 21 te doen met Jesus se afwysing van dié legalisme. Yarnold (1968: 270) verwys hierna soos volg:

He (Jesus - AG v A) takes the word teleios from the spiritual vocabulary of his hearers (die Joodse leiers - AG v A) and gives it a twist: If you really want to be téleios you must love friend and foe alike (Mt 5: 48), you must get rid of this money which is holding you back from whole-hearted service of God (Mt 19: 21). If you really want to be téleios, to be faithful to all that is noble in the pharisaic ideal, you must be rid of the legalism which so easily taints it.

Przybylski (1980) het in hierdie verband aangetoon dat die terme 'volmaak' (téleios) en 'geregtigheid' (dikaiosúnê) in die Matteusevangelie deel is van aanverwante begrippe. Beide terme verwys na 'n lewenshouding wat die vrug is van die korrekte interpretasie van die tora. 
Dikaiosyne is a term which refers to conduct according to a norm which in this case is the law. Both the disciples and the scribes and Pharisees have righteousness insofar as both groups live according to the demands of the law. This, however, does not mean that the righteousness of the two groups is identical. Jesus demands that the righteousness of the disciples is to exceed that of the scribes and the Pharisees. This does not mean that the disciples are to live according to a different law but they are to live according to a different interpretation of the law .... The goal of this type of conduct is perfection .... The disciples are to observe everything that Jesus commanded (Przybylski 1980: 87).

In die lig van die aangehaalde opmerkings van Yarnold en Przybylski hierbo, is dit daarom korrek en waardevol dat Engelbrecht (1985: 151, 154) in sy doktorale proefskrif by implikasie 'n verband lê tussen die woorde 'barmhartigheid' (éleos) en 'volmaak' (téleios) aan die een kant en dikaios aan die ander kant. Hy hanteer eersgenoemde twee woorde tereg in die gebruiksarea van die nie-formalistiese wetsgehoorsaamheid. Die verwysing van laasgenoemde Griekse woord in die Matteusevangelie kan weergegee word as 'konformerend met God se standaard' (vgl Van Aarde 1986b: 175-176). Engelbrecht verwys na éleos ('lojaliteit' as vertaling van hierdie woord is minder geslaagd) as die 'sentrale senuwee' van die korrekte wetsgehoorsaamheid. Dit is ongetwyfeld wel só. In afdeling 4.3.3.2 kom ons terug op die betekenis wat bogenoemde verbandlegging vir die seunskap-motief in die Matteusevangelie het. Daar toon ons aan dat die 'volmaakte dissipel' net soos Jesus 'seun van God' genoem word.

Om dissipel van Jesus te wees, is om Hom te volg. Kingsbury (1978) het oortuigend aangetoon dat die 'volg' (akolouthein) van Jesus 'n prominente tema in die Matteusevangelie is. Vir ons doeleindes is dit opvallend dat sowel die ryk jongman (Matt 19: 21) as die dissipels (Matt 19: 27) moes hoor dat as iemand téleios wil wees, dit wil sê sy goed en familie prysgee, hy Jesus ook moet volg. Om Jesus, die beliggaming van die wil van God, te volg, is om gehoorsaam te wees aan sy geradikaliseerde interpretasie van die wil van God.

\subsubsection{Matteus 22}

Die laaste drie gevalle waar die aanspreekvorm didáskale in die Matteusevangelie voorkom, word almal in hoofstuk 22 aangetref. Al drie hierdie perikope beklemtoon eweneens die opposisie tussen Jesus en die Joodse leiers met betrekking tot die interpretasie van die tora. 
Matteus 22: 15-22 (kyk vs 16) handel oor die vraag of aan die keiser belasting betaal moet word of nie. Hill (1972: 303-304) lewer onder andere die volgende kommentaar hierop:

The question on which Jesus is asked to give an authoritative opinion is not one merely of expediency or civil law, but of a theological nature: In the eyes of God (i.e. in the light of the law) is it permissible to pay tribute? ... this (is a) kind of question exercised (in) the minds of the rabbi's.

Matteus 22: 23-33 (kyk vs 24) het betrekking op die kwessie in verband met die Sadduseërs se opinie oor die opstanding uit die dood. Hiervan sê Schlatter (1963: 651, 654):

Der Pentateuch (Mōusēs eîpen) soll Auskunft geben über die Auferstehung. Die Saddukäer und die Pharisäer verlangten von einem theologischen Beweiss, dass er aus der Thora geführt werde. Nur diese anerkannten die Saddukäer als Gesetz ... Nach dem Urteil der Saddukäer schweigt die Thora nicht nur von der Auferstehung, sondern sie schliesst sie positiv aus ... Auch Jesus ruft the Thora für seine Verheissung an (vs 32) ....

Jesus se oordeel is dat die Sadduseese teologie die tora 'vereng' en 'arm maak' (vgl Schlatter 1963: 653). En wat die derde geval betref, naamlik Matteus 22: 34-40 (kyk vs 36), het ons te doen met die kwessie in verband met die kern van die tora (entolē megálē en tō nómōo). Hultgren (1979: 186) is reg as hy sê dat die resultaat van die vraag hieroor uitgeloop het op 'n strydgesprek waarin die dubbele liefdesgebod deur Jesus aangedui is as die sleutel tot die korrekte interpretasie van die wet en die profete.

\subsubsection{Kúrios}

Die term kúrios of die aanspreekvorm kúrie vir Jesus het nie deurgaans in die Matteusevangele die funksie van ' $n$ erebenaming nie. In Matteus 21: 3, byvoorbeeld, word die term gebruik as 'n verwysing na ò Jesus as die (nuwe) eienaar van die donkie (Foerster 1938) of na die werklike eienaar daarvan (Klostermann 1971: 166; Schmid 1965: 299). Hahn (1974: 85-86), Bornkamm (1961: 38-39), Gaechter (1963: 656) en Kingsbury (1975a: 108), onder andere, meen dat daar wel 'n Christologiestitulêre motief agter die gebruik van die term kúrios in Matteus 21: 3 geleë is. Eersgenoemde drie geleerdes reken dat Matteus hier' $n$ titel vir die voor-pase Jesus gebruik wat by wyse van antisipasie verwys na wat 
Hy eers by sy verhoging (opstanding) sal wees. Volgens Kingsbury moet die gebruik van die term hier nie aan Matteus se redaksionele aktiwiteit toegeskryf word nie. Matteus het dit van Markus oorgeneem. Vir Matteus het dit ' $n$ 'auxiliary'-funksie deurdat die 'titel' kúrios hier die ander Christologiese titels wat as Matteusredaksie prominent in die verband van Matteus 21: 1-9 figureer, naamlik 'Seun van Dawid' (vs 59) en 'Koning' (vs 3), onderbou. Volgens Kingsbury beklemtoon die kúrios-benaming hier die goddelike gesag waarmee Jesus as die 'Koning' opdrag gee om die donkie vir sy diens op te eis sodat Hy as 'Seun van Dawid' Jerusalem kan binne ry.

Die term kúrios word ook nie uitsluitlik vir Jesus aangewend nie. In onder andere Matteus 1: 22 en 4: 10, byvoorbeeld, word Jahwe kúrios genoem en in Matteus 27: 63 spreek die Joodse leiers Pilatus respekvol as kúrie $=$ 'meneer'/'u edele' aan. In Matteus 24: 46 funksioneer die term kúrios in 'n gelykenis as min of meer ' $n$ sinoniem van die term oikodespótés wat ons insiens nie as 'n Christologiese titel opgeneem kan word nie. Kingsbury (1975b: 255) meen egter dat kúrios in Matteus 24: 46 wel as 'n Christologiese titel funksioneer. Hy reken dat hierdie die enigste plek in die Matteusevangelie is waar kúrios nie as ' $n$ 'auxiliary title' aangewend is nie. Volgens Kingsbury moet dit hier opgeneem word as op dieselfde vlak as die titels 'Seun van Dawid', 'Seun van die mens' en 'Seun van God'.

In die gevalle waar die woord kúrios in die Matteusevangelie as 'n erebenaming funksioneer, word die gesag waarmee Hy optree, beklemtoon.

Wanneer Matteusnavorsers vra na die funksionaliteit van die kúriosbenaming in hierdie evangelie, is hulle ons insiens op die verkeerde spoor deur hulle te laat lei deur die studies van enersyds Bousset (1967) en andersyds van Conzelmann (1977). Wat Bousset betref, is daar ondersoekers soos onder andere Hurtado (1979) wat hom as verkeerd en onder andere Hahn (1974) wat hom as reg wil probeer bewys. Volgens Bousset sou die aanwending van die titel kúrios slegs op nie-Palestynse bodem moontlik wees. Wat Conzelmann betref, is daar ondersoekers wat van die resultate van sy studie van die titel kúrios in die Lukasevangelie oordra na die Matteusevangelie. Volgens Conzelmann het die kúrios-titel in die Lukasevangelie nie 'n ontologiese drawydte as sodanig nie. Dié titel is volgens hom ' $n$ aanduiding van 'n 'funksionele kompromis' wat die gemeente tussen die werk van Jesus en die werk van God in die uitvoering van die 'heilsgeskiedenis' gesluit het. Op grond van hierdie 'kompromis' kan daar ' $\mathrm{n}$ verskil in die gebruik van 
die titel ten opsigte van onderskeidelik die voor-pase periode en die na-pase periode afgelees word. Oorgedra na die Matteusevangelie, probeer Vögtle (1964) en Bornkamm (1964), byvoorbeeld, aantoon dat die motief van goddelike gesag agter die gebruik van die kúrios-titel in die Matteusevangelie geleë is.

Die insig dat Matteus die kúrios-benaming as aanduiding van Jesus se goddelike gesag aanwend, is korrek. Die drawydte van die gesagmotief agter die kúrios-benaming moet egter nie in die sfeer van die konsep 'heilsgeskiedenis' gesoek word nie, maar in dié van die interpretasie van die tora. Hierdie 'gesag' het betrekking op Jesus se radikale interpretasie van die tora wat in ooreenstemming met die wil van God is, in onderskeid met die interpretasie daarvan deur die Joodse leiers (vgl Rogers 1973: 265). Verder is die gebruik van die kúrios-benaming ' $n$ aanduiding van die perspektief van waaruit die dissipels en die Joodse skare in die Matteusevangelie gekarakteriseer word. Waar die Joodse leiers deur middel van onder andere hulle ironiese benaming didáskalos vir Jesus eenduidig geteken word as sy opponente, daar word die kompleksiteit van die karakter van die dissipels as 'kleingelowiges' en die Joodse skare en heidene as potensiële navolgers van Jesus deur onderskeidelik hulle benaming kúrios vir Hom belig.

\subsubsection{Matteus 12: 1-8}

In Matteus 12: 1-8 (kyk vs 8) word Jesus se gesag waarmee Hy die wet in verband met die sabbatdag reg interpreteer en besluit wat op die sabbatdag geoorloof is en wat nie, as gevolg van onder andere die benaming kúrios eksplisiet gestel.

\subsubsection{Matteus 14: $22-33$ en 17: 1-19}

In Matteus 14: 22-33 (kyk vss 28-29 en vs 30) en Matteus 17: 1-19 (kyk vs 4) funksioneer die benaming 'Seun van God' meer prominent, maar die benaming kúrios waarmee Petrus in beide passasies vir Jesus aanspreek, getuig van Petrus se 'insig' in die gesag waarmee Jesus opdragte kan gee. In eersgenoemde geval toon hy die insig dat Jesus die gesag het om die opdrag te gee dat Petrus op die water kan loop en die gesag en mag om die sinkende Petrus te red (vgl ook Matteus 8: 25), en in laasgenoemde geval die insig dat Jesus, as Hy wil, met gesag die opdrag kan gee om drie hutte (een elk vir Jesus, Moses en Elia) te bou.

\subsubsection{Matteus 16: 21-28 en 18: 21-35}

Sowel Matteus 16: 21-28 (kyk vs 22) as Matteus 18: 21-35 (kyk vs 21) kan as 'didaktiese' gedeeltes bestempel word waarin Petrus vir Jesus as 
kúrie aanspreek. Jesus se gesagvolle 'onderrig' en Petrus se erkenning dat Hy wel met sodanige gesag beklee is, word deur onder andere hierdie aanspreekvorm uitgedruk. Tegelykertyd getuig beide passasies van 'n leemte in Petrus se insig. In eersgenoemde perikoop kom 'n lydensaankondiging, 'n berig oor Petrus se verleentheid en die sogenaamde 'Satanswoord' voor (kyk Van Aarde 1982b). Laasgenoemde perikoop bevat as inleiding Petrus se vraag in verband met 'vergifnis van sonde' en Jesus se antwoord in die vorm van die gelykenis oor die 'bose slaaf'.

\subsubsection{Matteus 8: $1-4 ; 8: 5-13 ; 15: 21-28 ; 7: 21 ; 25: 11 ; 25: 31-46$ en 26: 17-25}

Individue onder die Jodese skare (Matt 8: 1-4-kyk vs 2 - en Matt 17: 14-18 - kyk vs 15) en die heidene (Matt 8: 5-13-kyk vss 6 en 8 - en Matt 15: 21-28 - kyk vs 27), wat Sand (1974: 164) die 'outcasts' noem, spreek ook by geleentheid Jesus as kúrios aan. Hulle spreek Hom so aan omdat hulle waarskynlik meen dat $\mathrm{Hy}$ die gesag en mag het om te genees.

Hiermee word hulle deur Matteus as potensiële navolgers van Jesus geteken. Die potensiële navolgers, sowel as die dissipels, moet egter hoor dat nie elkeen wat 'Here, Here' vir Hom sê, in die koninkryk van die hemel sal ingaan nie (vgl Matt 7: 21; 25: 11), maar alleen dié wat die wil van die Vader, soos Jesus dit leer, doen.

Hierdie aspek word veral in die berig oor die laaste pasgamaaltyd (Matt 26: 17-25) en die gelykenis in verband met die eindoordeel (Matt 25: 31-46) beklemtoon. In eersgenoemde perikoop spreek die een dissipel Jesus as kúrios aan (Matt 26: 22) en die ander dissipel (Judas Iskariot) spreek Hom as rabbi aan (Matt 26: 25). In laasgenoemde perikoop spreek die dikaioi (die 'skape') Hom aan as kúrios (Matt 25: 37) en die ander (die 'bokke') spreek Hom ook as kúrios (Matt 25: 44) aan die een ontvang seën en die ander oordeel. Op grond van hierdie twee perikope is dit duidelik dat nie elkeen wat vir Jesus kúrie kürie sê, in die koninkryk van die hemel sal ingaan nie.

\subsubsection{Samevatting}

Ons kan die perspektief wat deur die benaming kúrios uitgedruk word, soos volg in die woorde van Sand (1974: 164) saamvat:

Die Legitimation, Jesu als Hern zu bezeichnen, het Matthäus zunächts einmal seinen vorgebenen Quellen entnommen; er hat sie aber vor allem von der Tatsache abgeleitet, das seine Ge- 
meinde nicht mehr den jüdischen Rabbinen verplichtet ist, sondern einem neuen Herrn, die sich von diesen Rabbinen unterscheidet, und zwar vor allem durch seine vom Vater empfangene vollmacht und durch seine Barmherzigkeit gegenüber den Verachteten 'outcasts'. Um dies immer wieder zu betonen, hat Matthäus den Ruf nach Erbarmen (eléēson) sowohl an den Kyrios (9, $27 ; 15,22 ; 17,15 ; 20,30)$ als auch an den Davidssohn $(9,27 ; 15,22$; $20,30)$ gerichtet dargelegt (my beklemtoning).

\section{2 'Seun van Dawid', 'Christus', 'Koning van die Jode' en 'Profeet'}

\subsubsection{Inleiding: Verband tussen kúrios-benaming en 'Seun van Dawid'}

Ondersoekers soos Bornkamm (1961: 30-31), Strecker (1966: 118-120), Hummel (1966: 121-122), Walker (1967: 129-132), Suhl (1968: 69, 75-76, 81) en Sand (1974: 47, 50, 62-67) is op grond van onder andere Matteus 22: 41-46 van mening dat die titel 'Seun van Dawid' in die Matteusevangelie teenoor die titel 'Here' funksioneer. Eersgenoemde sou die aanduiding wees van die aardse Jesus en laasgenoemde die aanduiding van die opgestane Jesus. Indien hierdie ondersoekers reg is, sou dit beteken dat ons ons bespreking van die 'Seun van Dawid'benaming deur hierdie binêre relasie sal moet laat lei. Hoewel dit só is dat die 'Seun van Dawid'-benaming alleen met betrekking tot die aardse Jesus in die Matteusevangelie voorkom, is dit egter nie korrek om te beweer dat die kúrios-benaming alleen met betrekking tot die opgestane Jesus gebruik word nie. Op grond van ons voorafgaande bespreking van die funksie van die kúrios-benaming is ons van mening dat' $n$ aspek van Conzelmann (1977: 165-166) se bevinding ten opsigte van die funksie van die kúrios-titel in die Lukasevangelie ook in die Matteusevangelie aanwysbaar is. Dit is naamlik dat die kúrios-titel ook vir die aardse Jesus gebruik word en dan nie noodwendig in ' $n$ antisiperende sin nie. Die 'Seun van Dawid'-benaming moet ons insiens nie ondersoek word vanuit die perspektief 'voor-pase' teenoor 'na-pase' nie. Die verband wat daar tussen die benamings kúrios en huiòs David bestaan, is geleë in die barmhartigheid-motief (vgl opmerking van Sand 1974: 164 hierbo). Hierdie motief is op sy beurt uitdrukking van die grondliggende Leitmotif God-by-ons. As sodanig is Jesus die beliggaming van die wil van die Vader, soos uitgedruk in die wet en die profete. 


\subsubsection{Blindheid-motief en Ou-Testamentiese verwagting}

Wat vir die doel van ons studie belangrik en opvallend is, is die feit dat naas die verteller self, slegs die objek van Jesus se sending, dit wil sê die Joodse skare en die heidene, na Hom as 'Seun van Dawid' verwys, en nie die dissipels of die Joodse leiers nie. Hierdeur manifesteer 'n bepaalde perspektief van waaruit die Joodse skare en die heidene met betrekking tot Jesus vertel word. Twee sake kan deur ons afgelei word wanneer ons op die gedeeltes let waar die benaming 'Seun van Dawid' voorkom.

Eerstens is dit opvallend dat al die passasies waarin die Joodse skare (Matt 9: 27; 12: 23; 20: 30 en 21: 15) en die heidene (Matt 15: 22) Jesus as 'Seun van Dawid' aanspreek, genesingsperikope is (vgl o a Gerhardsson 1979: 86-88) en dat almal, behalwe Matteus 15: 21-28, op een of ander wyse te doen het met die genesing van blindes. Matteus 21: 9, die intog in Jerusalem, is ' $n$ uitsondering omdat dit nie direk op 'n genesing betrekking het nie. Tog staan die intoginsident in noue relasie met die daaropvolgende genesingsinsident wat in die tempel afgespeel het (Matt 21: 15).

Die rol van sowel die Joodse skare as die heidene in die Matteusevangelie is dié van potensiële navolgers van Jesus. Anders as die heidene is die karakterisering van die Joodse skare nie eenduidig van aard nie. Soms is die beslissing van die Joodse skare ten opsigte van Jesus 'positief' (o a Matt 15: 31; 21: 9), maar ander kere 'negatief' (o a Matt 13: 53-58). En uiteindelik skree hulle: 'Kruisig hom! Ons aanvaar die verantwoordelikheid vir sy bloed, ons en ons kinders!' (Matt 27: 23, 25). Met behulp van onder andere die genesing-van-blindes motief en die aanspreekvorm 'Seun van Dawid' vir Jesus word die Joodse skare en die heidene implisiet in die rigting gestuur om Jesus as die gesalfde gestuurde vir Israel te aanvaar. Daarom beklemtoon Matteus dat die heidensending nie die sending na die Joodse skare uitsluit nie.

Tweedens wil die verteller deur middel van onder andere die benaming 'Seun van Dawid' die aard van Jesus se sending koppel aan die Ou-Testamentiese verwagtinge in verband met die ideale 'gesalfde' (christós), 'koning van die Jode' (basileùs tōn loudatōn) en die rol van 'n 'profeet' (profētēs):

Die benaming 'Christus' kom in die Matteusevangelie voor as 'n eienaam (Matt 1: 1, 18; 16: 21) sowel as 'n erenaam, dit wil sê as 'n Christologiese titel. Laasgenoemde gebruik is ' $n$ wyse waarop die verteller Jesus teken as dié Een wat gekom het ooreenkomstig die beloftes van die profete en as sodanig deur Israel verwag is. So gesien, 
is ook die benaming 'Christus' saam met die benaming 'Seun van Dawid' verbind aan die vervulling van die (wet en die) profete en aan die idee dat God by ons is. Dieselfde nuanse vind ons in Matteus se gebruik van die benaming 'Koning van die Jode'. Vanuit die gesigshoek van Herodes die Grote (Matt 2: 2, 4, 13, 16), Pilatus en die Romeinse kohort (Matt 27: 11, 17, 22, 29, 37), die Romeinse soldate (Matt 27: 27-31) en die Joodse leiers (Matt 26: 63, 68; 27: 37, 41-42) het hierdie benaming ' $n$ politiese konnotasie. Vanuit die gesigshoek van die verteller word die benaming deur die kneg-motief gekenmerk (vgl Matt 12: 18). Kingsbury verwys onder andere soos volg na Matteus se visie van Jesus as 'koning' en 'kneg'

In the pericope 27: 27-31, Matthew provides a detailed sketch of the true nature of Jesus' kingship: As he stands draped in a scarlet robe with a crown of thorns on his head and a reed for a sceptre in his right hand, the soldiers abuse him and, kneeling in mock obeisance before him, hail him as 'King of the Jews'. Hence, if 'King' marks Jesus Messiah as a political throne-pretender in the eyes of his enemies, in the eyes of Matthew it marks him as the one in the line of David $(1: 6,20,25 ; 21: 9)$ who establishes his rule, not by bringing his people to heel, but by suffering on their behalf (Kingsbury 1977: 34).

As 'Koning' en as 'Kneg', as 'Seun van Dawid' en as 'Here' (kúrios) laat die Matteaanse Jesus die wil van God seëvier (Matt 12: 20) deur die wet te interpreteer as ' $n$ opdrag tot barmhartigheid (Matt 12: 6-7). Daarom genees Hy mense vanuit die Joodse skare (Matt 12: 9-13; 22-23) en vestig die heidene hulle hoop op Hom (Matt 12: 21). Maar die Joodse leiers, getuies van Jesus se genesings, wil Hom doodmaak (Matt 12: 14). Hulle verwerp Hom as 'Seun van Dawid', as 'Christus' en as 'Koning van die Jode' (vgl Matt 21: 14-15; 27: 29, 37), net soos hulle vadere die profete verwerp het. Hiervan is Jesus se 'wee julle'-uitspraak in Matteus 23: 29-32 'n direkte en skerp aanduiding. Derrett lewer soos volg kommentaar op hierdie 'wee julle'-uitspraak wat gerig is aan die Joodse leiers as profetemoordenaars:

The scholars of Jesus' time and later called themselves 'builders', 'builders in the Torah'. They applied to themselves, one may suspect, the passages in the prophets which speak of the builders of Jerusalem. They were certainly proud of their scholarship, as if it were constructive as well as laborious. Perhaps Jesus said something like this: 'You say you are the builders (and I am 
knocking down your structure with my unexpected interpretations of the Torah ...). Of what are you the builders? You are building the tombs of the prophets ... (Derrett 1968: 193).

Op hulle beurt beskuldig die Joodse leiers Jesus dat Hy 'n handlanger van Satan is (Matt 12: 22-24). Hierdie beskuldiging word ironies juis gegrond op die genesingsdade van Jesus as 'Seun van Dawid'. Die Joodse leiers se optrede teenoor Jesus korreleer met hulle beeld as 'blinde leiers' van die volk (vgl Matt 15: 14; 23: 16). Die 'insig' wat die Joodse skare op grond van die genesing van hulle 'blindheid' gekry het, behoort dus in afgeleide sin verband te hou met die besef dat hulle leiers in werklikheid volgens Matteus 'blinde leiers' is. Vanweë die ambivalensie in die optredes van die Joodse skare as karaktergroep is hulle 'sien' egter nie werklik 'sien' nie en hulle 'hoor' nie werklik 'hoor' nie (vgl Matt 13: 13). Die Joodse skare se 'insig' ten opsigte van Jesus se identiteit bestaan hoogstens daaruit dat hulle Hom aanroep as 'Seun van Dawid' en as 'profeet van Nasaret' (Matt 21: 9-11) - dié Een wat mag het om te genees. Hulle dring egter nie werklik deur tot sy ware aard nie.

Beare, in sy kommentaar op Matteus 21, formuleer hierdie perspektief van waaruit die Joodse skare, met behulp van die benaming 'Profeet' vir Jesus, geteken is:

The masses (hoi óchloi, 'the crowds') look upon Jesus as a prophet .... For Matthew this means that they still do not know him for what he is in truth - the Messiah, the Son of God. For the moment, their respect for Jesus as a prophet is so great that the authorities do not dare to offend them by seizing Jesus forthwith (Mt 21: 46); a few days later, they will be ready to shout, 'Let him be crucified' (27: 22f.) (Beare 1981: 431).

Met die benaming 'Profeet' wat die Joodse skare vir sowel Jesus (Matt 16: 13-14; 21: 11, 46) as Johannes die Doper (Matt 14: 5; 21: 26) gebruik, plaas die verteller Jesus en Johannes die Doper in kontinuerende lyn met die (wet en die) profete. Ook die dissipels word in die raamwerk van dieselfde strekking so genoem (Matt 10: 41; 23: 34). Wanneer die Joodse skare Jesus so noem, beklemtoon die verteller egter daarmee dat hulle perspektief ambivalent en derhalwe onvolledig is. Die verteller laat Jesus indirek verklaar dat Hy méér is as 'n 'profeet' (Matt 11: 9) en direk dat $\mathrm{Hy}$ as 'Here' méér is as 'Seun van Dawid' (Matt 22: 41-46).

Die perspektief van waaruit die Joodse skare geteken word, is dus dié 
van potensiële navolgers van Jesus, maar tegelykertyd van mense met gebrek aan volkome insig - 'n 'kortsigtigheid' wat deurgaans in die hele middelstuk van die Matteusevangelie (Matt 4: 23-25: 46) dreig om met dié perspektief te versmelt van waaruit die Joodse leiers geteken word. Dit gebeur inderdaad in die slot van die evangelie. In dié lig gesien, het die 'vervloeking van die vyeboom' waarskynlik op sowel die Joodse skare as op die dissipels betrekking by wyse van hipotese (Matt 21: 18-22). Hierdie perikoop moet waarskynlik gelees word teen die agtergrond van die twee insidente wat volgens die vertelling die vorige dag in die tempel afgespeel het en in die voorafgaande twee perikope berig is. Dit handel onderskeidelik oor die 'intog in Jerusalem' (Matt 21: 1-11) en die 'suiwering van die tempel' (Matt 21: 12-17). In altwee laasgenoemde perikope vind ons die aanroep hōsanna tō huiō David in die mond van die Joodse skare. (Die 'kinders' in Matt 21: 15 vervul dieselfde rol as dié van die Joodse skare - kyk Van Aarde, 1982a: 87-94). Iemand kan 'Here Here' sê, of 'Prys die Seun van Dawid', maar as hy nie die wil van die Vader, soos Jesus dit leer, doen nie, sal hy soos 'n vyeboom verdroog, omdat hy slegs blare en nie ook vrugte dra nie.

\section{3 'Seun van die mens' en 'Seun van God'}

\subsubsection{Inleiding}

Navorsing oor die historiese en teologiese problematiek van die Christologiese titels 'Seun van die mens' en 'Seun van God' het feitlik onoorsigtelik geword. Wat eersgenoemde titel betref, verwys ons na onder andere die werke van Kümmel (1980: 50-84) en Higgins (1980: 29-53) vir 'n oorsig van dié navorsing en wat laasgenoemde titel betref, -na die werk van Van Iersel (1964: 3-8) asook dié van onder andere Bieneck (1951), De Kruijf (1962), Pokorný (1971), Hengel (1976), Hahn (1974: 280-333) en Delling (1977).

Ons het reeds vroeër (afdeling 3.2) gewys op Kingsbury se eensydige benadering waarvolgens die 'Seun van God'-titel 'n inklusiwistiese konsep in die Matteusevangelie sou wees wat ò die ander titels se verwysingsraamwerke in homself bevat of waarby titels (byvoorbeeld die kúrios-titel) op 'n auxiliary-basis as ondergeskik funksioneer. Ons kan egter so 'n siening nie onvoorwaardelik steun nie. Insgelyks kan ons saam met Hill (1979) nie aan Kingsbury gelyk gee dat die 'Seun van God'-titel en die 'Seun van die mens'-titel in onlosmaaklike relasie in die Matteusevangelie funksioneer en dat 'the difference between the two more a matter of function than of content' is nie (Kingsbury 1977: 
56). Op 'n ander plek sê Kingsbury (1975c: 202): '. . . they (die 'Seun van die mens' en die 'Seun van God'-benaminge resp - AG v A) describe Jesus, the one from the standpoint of the world and the other from the standpoint of the church ....'

Volgens herdie uitgangspunt van Kingsbury openbaar die volgende patroon hom konsekwent in die Matteusevangelie:

... if Matthew views Jesus in his interaction with his disciples during his ministry and with his church following Easter as the Messiah, the Son of God, he views him in his interaction with the world, first Israel and then the gentiles, as the Son of man. Still, at the consummation of the age, when Jesus will appear visibly as the Judge and Ruler of the universe so that the whole world will see what until that time only the eyes of faith had ever been given by God to perceive, then says Matthew, the distinction between Jesus as the Son of God and Jesus as the Son of man will fall away; indeed, at the consummation both church and world will behold Jesus in all the majesty of God as the Son of man (Kingsbury 1977: 57).

Vyf redes kan aangevoer word waarom ons nie Kingsbury se siening in verband met die sogenaamde binêre funksionaliteit van die titels 'Seun van die mens' en 'Seun van God' in die Matteusevangelie kan steun nie. Eerstens, dit sou alleen legitiem wees om te beweer dat die 'Seun van God'-titel, in sowel die voor-pase as die na-pase periode, die perspektief is waardeur die verteller die interrelasie tussen Jesus en die kerk spieël, as die 'Seun van God'-titel die presiese sjabloon van die God-by-ons konsep is. En dit is nie sonder meer die geval nie. Tweedens, die 'Seun van God'-titel figureer nêrens in die Matteusevangelie in uitsprake wat betrekking het op die wederkoms nie. Dit is geforseerd om op grond van hierdie afwesigheid in die logia oor die wederkoms te beweer dat die 'Seun van die mens'-titel wat wel in sodanige verbande voorkom, met die 'Seun van God'-titel by die wederkoms saamgeval het. Derdens, geen onderskeid word deur Kingsbury tussen die onderskeie rolverdelings van die Joodse leiers en die Joodse skare getref nie. Die Joodse leiers as die antagoniste en die Joodse skare as die objek van Jesus se sending word simplisties in een asem as 'Israel' bestempel en 'Israel' saam met die 'heidene' is die 'wêreld'. Hierdeur word die basiese binêre relasies tussen die karakters in die Matteusevangelie vermeng met die gevolg dat die intrige in die Matteusvertelling ons insiens nie korrek ontleed word nie. Vierdens, 
Hill (1979: 144) is korrek wanneer hy daarop wys dat dit nie aanvaarbaar is om die ma van Jakobus en Johannes (Matt 20: 28) as 'n karakter op dieselfde vlak as die Joodse leiers of Judas Iskariot te beskou, net omdat Jesus in sy gesprek met haar na Homself met die frase 'Seun van die mens' verwys nie. Vyfdens, Kingsbury maak nie regtig erns met die feit dat die frase 'Seun van die mens' in die Joodse intertestamentêre literatuur gewoonweg die 'algemene betekenis' van die eerstepersoonpronomen 'ek' of 'mens' het nie (vgl Vermes 1973: 145-156, 160-186; 1978: 27). Sy vertaling van die frase in Engels met 'this man' (Kingsbury 1985: 68-74) toon dat hy bewus is van hierdie Aramese gebruik. Hy span selfs 'n latere werk van Vermes in as bevestiging van sy Engelse vertaling. Die verskilpunt tussen ons en Kingsbury het in hierdie verband nie, soos by Hill (1984), as sodanig betrekking op sy Engelse vertaling nie. Dis bloot dat ons nie kan aanvaar dat die frase in alle gevalle in die Matteusevangelie as 'n erebenaming funksioneer nie. Aan die ander kant is Hill (1984) ook nie korrek om te meen dat die frase glad nie die funksie van 'n erebenaming in die Matteusevangelie het nie.

\subsection{2 'Seun van die mens'}

\subsubsection{Filologiese en titulêre gebruik}

Sonder om Vermes in alle opsigte gelyk te gee, moet ons aanvaar dat heelwat van die 'Seun van die mens'-logia in die Matteusevangelie nie die funksie van benaming het nie. Voor die studie van Vermes het daar feitlik konsensus onder Nuwe-Testamentici bestaan dat hierdie logia in die Sinoptiese Evangelies in drie kategorieë uiteenval, naamlik dié wat te doen het met die komende 'Seun van die mens' in 'n regtersfunksie, dié wat te doen het met die openbare optrede van Jesus en wat gewoonlik dieselfde verwysing het as die eerstepersoon-pronomen en ten slotte dié wat betrekking het op die lyding en sterwe van Jesus (vgl o a Aulén 1976: 111-112). Iemand soos Jeremias (1971: 247-248) is egter van oortuiging dat van die nege en sestig keer dat dié frase in die Sinoptiese Evangelies voorkom, dit tien keer wel die funksie van 'n Christologiese titel het en dat dit almal met die wederkoms van Jesus te doen het (Jeremias 1971: 251). Sewe van hierdie tien logia kom in die Matteusevangelie voor, naamlik Matteus 10: 23; 24: 27, 30, 37b $=39 \mathrm{~b}$; 25: 31 en 26: 64. Hierdie waarneming dat die wederkoms-motief in Matteus se aanwending van die 'Seun van die mens'-frase baie prominent is, het Tödt (1959: 62-88; 128-130;138-140), sonder dat hy 'n 
onderskeid getref het tussen die 'filologiese' en die 'titulêre' gebruik daarvan, op grond van 'n redaksie-kritiese ondersoek ook gemaak.

\subsubsection{2 'Seun van die mens' as komende regter}

Uitgaande van Jeremias se bevinding (vgl egter Vermes 1978: 21-22 se kritiek op Jeremias), is dit vir die doeleindes van ons studie voldoende om die verteller van die Matteusevangelie se karaktertekening van Jesus wat hy deur middel van die 'Seun van die mens'-benaming uitdruk, te beskryf as ten minste dié van komende regter. By die wederkoms sal Jesus as die 'Seun van die mens' die Joodse leiers (Matt 10: 23 en 26: 64) en ook 'al die stamme van die aarde' (Matt 24: 30) oordeel. Hy sal 'n skeiding teweegbring tussen die geseëndes wat die wil van die Vader gedoen het en die hipokriete wat gemene saak met die gesindheid van die Joodse leiers gemaak het (Matt 24: 27, 30, 37b $=39 \mathrm{~b}$ en 25: 31). Die perspektief van waaruit Jesus met behulp van die benaming 'Seun van die mens' geteken word, is met ander woorde dié van die regter wat by die wederkoms oordeel, met as maatstaf die gehoorsaamheid aan die wil van God, soos dit in Jesus self beliggaam is.

\subsection{3 'Seun van God'}

\subsubsection{Inleiding}

Hoewel ons Kingsbury dus nie gelyk gee in verband met sy mening oor die funksionele interrelasie tussen die Christologiese titels 'Seun van die mens' en 'Seun van God' nie, is ons tog van oortuiging dat hy en baie ander Matteusnavorsers met reg die funksionele belang van die 'Seun van God'-benaming in die Matteusevangelie beklemtoon. Dit is ongetwyfeld so dat hierdie benaming 'expresses for Matthew the deepest mystery of the person of Jesus Messiah (Kingsbury 1975a: 82). In ons bespreking van die bepaalde perspektief wat met betrekking tot Jesus deur die benaming 'Seun van God' uitgedruk word, vermy ons doelbewus die problematiek in verband met die vrae of die benaminge 'Seun van God' en die absolute 'die Seun' 'n tradisieontwikkeling sou verteenwoordig (vgl by Hahn 1974: 319-333 en Van Iersel 1964: 185191). Ons vermy ook die vraag of die seunskap-motief in die Matteusevangelie alleen binne die raamwerk van die kontemporêre Judaïstiese 'koninklike messianologie' sonder invloed van die Hellenistiese theîs anèr-voorstelling sou figureer (vgl bv die bespreking van Pokorný 1971: 7-25, 39; Hengel 1976: 31-32; Jones 1979: 426) en/of deel sou wees van die veronderstelde kontemporêre Judaïstiese 'Seun van die mens'voorstelling (vgl bv Mowinckel 1956: 293-294; 366-368). 


\subsubsection{Seunskap-motief}

Ons gaan uit van die standpunt dat die benaminge ho huiòs en ho huiòs tôิ theô dieselfde funksionele drakrag in die Matteusevangelie het. Dit het deurgaans dieselfde basiese strekking wat die seunskap-motief genoem kan word. Hierdie motief word ook uitgedruk met benaminge soos 'my geliefde Seun', 'my Vader', 'ons Vader wat in die hemel is' ensovoorts.

Die seunskap-motief het in die Matteusevangelie in die eerste plek betrekking op Jesus, 'verwek deur die Heilige Gees' (Matt 1: 20) en daarom in die ontologiese sin 'Seun van God', en in die tweede plek op die dissipels as 'seuns van God', en 'broers' (Matt 5: 9, 45; 6: 9, 26; 7: 11; 12: 50 ensovoorts). Die basiese strekking van die 'Seun van God'benaming en die seunskap-motief in die Matteusevangelie is enersyds die besondere verhouding wat Jesus met God het en andersyds sy sending as 'Seun van God' wat tot uitdrukking kom in sy gehoorsaamheid aan die wil van die Vader. Toegepas op die dissipels as 'seuns van God', is dit soos Bauckham (1978: 258-259) dit uitdruk:

... Jesus' filial relationship to God and his filial mission from God are interrelated and the uniqueness of his sonship is to be found in this interrelation. He experienced his sonship both as an already given relationship and also as a responsibility to be fulfilled in obedient submission to the Father's will .... But it belongs to the unique quality of his sonship that it can be shared, or rather, that it must be shared. It is the imperative of his filial mission (and therefore essential to his sonship) to mediate to others his own filial relation to God. His sonship means this.

In afdeling 4.1.2.5 van ons studie is beredeneer waarom die dissipel wat 'seun van God' genoem kan word, volgens Matteus die 'volmaakte dissipel' is. Frankemölle (1974: 172) formuleer in hierdie verband soos volg: 'In der Qualifizierung des Jüngers als "Sohn Gottes" liegt die . . . (gegenwärtigen) Ermöglichung für ihn, ebenso "volkommen" (téleios) wie "sein Vater im Himmel" zu sein ...'

\subsubsection{Goddelike teenoor demoniese perspektief}

Die 'Seun van God'-benaming vir Jesus kom in die Matteusevangelie voor in die mond van 'bo-menslike' karakters, naamlik God ("'n stem uit die hemel' - Matt 3: 17/''n stem uit die wolk' - Matt 17: 5) en Satan/demone (Matt 4: 3, 6; 8: 28-29).

Soos Kingsbury (1984: 5-7) van 'God's evaluative point of view' 
praat, kan ons die uitdrukking 'demoniese perspektief' in hierdie verband met die teenoorgestelde verwysing gebruik. In afdeling 3.2 van ons studie het ons spesifiek na hierdie aspek van Kingsbury se narratologiese ondersoek van die Matteusevangelie verwys. Die opmerking wat ons daar gemaak het, naamlik dat David Hill se kritiek op die 1984-artikel van Kingsbury nie in alle opsigte toegegee kan word nie, moet in hierdie konteks verstaan word (vgl veral Kingsbury 1985: 63-66).

Sowel die dissipels (Matt 14: 33 en 16: 16) as die heidense offisier en soldate (Matt 27: 54) se belydenis van Jesus as 'Seun van God' spruit nie voort uit eie insig nie, maar uit 'n insig wat bekom is vanweë 'bo-menslike gebeure' wat as Christofanieë bestempel kan word. Dit is dus betekenisvol dat die vertelde karakters, naas God en Satan, wat die benaming 'Seun van God' vir Jesus gebruik, in die Matteusevangelie geteken word as karakters wat hulle in hulle onderskeie perspektiewe skaar hetsy by God hetsy by Satan: die dissipels en die heidense offisier en soldate in geloofsbelydenis; die Joodse leiers (Matt 27: 43) en die Joodse skare (Matt 27: 40) in godslastering. Die beeldwoord 'marionette' (vgl Kamphaus 1971: 50) gee treffend uitdrukking aan hierdie 'helpers'rolle van die dissipels as huidi theou/basiletas (Matt 5: 9, 45; 13: 38) in hulle verhouding met Jesus en dié van die Joodse leiers as huidi ponēroû/geénnēs (vgl o a Matt 13: 38; 23: 15) in hulle verhouding met Satan. Die Joodse skare (wat aanvanklik 'n rol vervul wat getuig van 'n 'onsekerheid' ten opsigte van die ware aard van Jesus) se finale 'beslissing' kom aan die lig wanneer hulle hulle deur die Joodse leiers laat oortuig en, net soos (vgl die bywoord homotos in Matt 27: 41) hulle 'leiers', Jesus as huios toû theoû by die kruisiging godslasterlik verwerp (Matt 27: 40). Die Romeinse offisier (en soldate) bely egter hierteenoor in geloof: 'Hierdie man was werklik die Seun van God' (Matt 27: 54). Hierdie 'belydenis' moet nie soos Walker (1967: 116), onder andere, opgeneem word as een van die bewyse van 'n draaipunt vanaf 'n partikularistiese tendens na 'n universalistiese tendens in die teologiese denke van Matteus nie (vgl Van Aarde 1982a: 87-94). Die uitroep van die heiden(e) hier kan ons insiens nie losgemaak word van die tempelmotief nie (vgl afdeling 4.2.2). Die skeur van die voorhangsel van die tempel is die finale vernietiging van die formalisme en partikularisme van die Judaïsme (soos deur die Joodse leiers in die Matteusevangelie verteenwoordig) en is die begin van die nuwe eskatologiese gemeente (vgl De Kruijf 1962: 105-107). 


\subsubsection{Samevatting}

Die twee aspekte rondom Matteus se funksionele aanwending van die 'Seun van God'-benaming met betrekking tot die karaktertekening van Jesus is aanvullend van aard: Die Seun wat sy herkoms vanuit die Vader in die hemel het en die Seun wat tot die dood toe absoluut gehoorsaam is aan die wil van die Vader. Hierdie seunskap-motief veroorsaak dat die begin van die Matteusevangelie die einde daarvan in die oog het en die einde is weer die begin - nie net teruggesien nie maar ook vorentoe, want nadat die epog van Jesus afgesluit is, het 'n ander een begin wat tot die voleinding van die tyd aanhou (kyk Van Aarde 1985: 272-273).

Met behulp van allerlei bewoordinge wat verband hou met die seunskap-motief, word Jesus trapsgewys geteken as die absoluut gehoorsame (kyk Kingsbury 1975a: 40-83): by verwekking, geboorte en kindheidsgeskiedenis, by doop en versoeking; by die Galilese openbare optrede en ten slotte by dood en opstanding. Soos die Joodse leiers en Satan in die begin saamstaan teen die Seun, so is hulle in die einde tydens die verhoor éénsgesind in hulle opposisie teen die Seun.

Wat die begin betref: Pesch (1967) het baie oortuigend ' $n$ Mosestipologiese tendens in Matteus 1-2 aangetoon. Hoewel Gibbs (1968: 38) verklaar: 'I have come not to praise the Matthaean "New Moses" but to bury him', bevat die volgende uitspraak van Gibbs, een waarmee ons instemming betuig, tog Moses-tipologiese implikasies: ' . . there is no Torah and Gospel in Matthew ... but there is rather the Good News that in Jesus the Torah, the demand of God's righteousness, is now totally and efficaciously present ....' Hill (1979: 144) reken dat Gibbs se formulering dat Jesus die 'geïnkarneerde tora' is, ' $n$ verfyning is van Kingsbury se allesoorheersende beklemtoning van die 'Seun van God'benaming in die teologie van Matteus. En ons meen dat hierdie stelling nie net korrek is nie, maar ook ' $n$ korrektief is ten opsigte van Kingsbury se oorbeklemtoning van die 'Seun van God'-benaming.

Wat die einde betref: Soos die gebruik van die benaming 'Leermeester' of 'Rabbi' vir Jesus in die mond van sy opponente 'n stuk ironie verteenwoordig, net so en veral is dit die geval met hulle gebruik van die benaming 'Seun van God' vir Jesus, veral net voor sy kruisiging. Hierdie ironie kom veral na vore in die verwysing van die hoëpriester na Jesus as 'Seun van God' (Matt 26: 64). Hoewel Kajafas se vraag - 'Is jy die Christus, die Seun van God?' (Matt 26: 63) - die waarheid weerspieël en daarom deur Jesus positief bevestig word met: 'Dit is soos u sê' (Matt 26: 64), is dit inderdaad 'n poging om Hom ironies van 
godslastering beskuldig te kry (Matt 26: 65). Een van die waarskynlike motiverings waarom die verteller enigsins toelaat dat die opponente van Jesus hierdie benaming vir Hom gebruik, word soos volg deur Kingsbury (1975c: 195 nota 3) geformuleer: '. . Matthew's ultimate concern is that Judaism should condemn Jesus, i.e. reject him totally, on the basis of nothing short of that title that conveys the deepest mystery of his person ....'

\section{Literatuurverwysings}

AULEN, G 1976: Jesus in contemporary historical research. Transl by Hjelm, IJ. Philadelphia: Fortress.

BALZ, HR 1967. Methodische Probleme der neutestamentliche Christologie. NeukirchenVluyn: Neukirchener Verlag.

BARR, DL 1976. The drama of Matthew's gospel: A reconsideration of its structure and purpose. ThD 24, 349-359.

BAUCKHAM, R 1978. The sonship of the historical Jesus in christology. S/Th 31, 245-260. BEARE, FW 1981. The Gospel according to Matthew: A commentary. Oxford: Blackwell. BIENECK, J 1951. Sohn Gottes als Christusbezeichnung der Synoptiker. Zürich: Zwingli.

BLAIR, EP 1960. Jesus in the Gospel of Matthew. Nashville: Abingdon.

BORNKAMM, G 1961. Enderwartung und Kirche im Matthäusevangelium, in Bornkamm, G, Barth, G \& Held, HJ, Überlieferung und Auslegung im Matthäusevangelium, 13-47. 2. Aufl. Neukirchen: Neukirchener Verlag.

BORNKAMM, G 1964. Der Auferstandene und Irdische: Mt 28: 16-20, in Dinkler, E (Hrsg), Zeit und Geschichte, 171-191. Tübingen: Mohr.

BORSCH, FH 1977. Matthew's intricate fabric. Interp. 31, 73-76.

BOUSSET, W 1967. Kyrios Christos: Geschichte des Christusglaubens von den Anfängen des Christentums bis Irenaeus. 6. Aufl. Göttingen: Vandenhoeck.

CONZELMANN, H 1977. Die Mitte der Zeit: Studien zur Theologie des Lukas. 6. Aufl. Tübingen: Mohr.

COPE, OF 1976. Matthew: A scribe trained for the kingdom of heaven. Washington: The Catholic Biblical Association of America.

CUllmaNN, O 1966. Die Christologie des Neuen Testaments. 4. Aufl. Tübingen: Mohr.

DAVIES, WD 1966. The setting of the sermon of the mount. 2nd ed. Cambridge: Cambridge University Press.

DAWSEY, JW 1983. The literary function of point of view in controlling confusion and irony in the Gospel of Luke. PhD-dissertation, Emory University, Atlanta, Georgia.

DE KRUIJF, TH 1962. Der Sohn des lebendigen Gottes: Ein Beitrag zur Christologie des Matthäusevangeliums. Romae: Pontificio Instituto Biblico.

DELLING, G 1977. Die Bezeichnung 'Sohne Gottes' in der jüdischen Literatur der hellenistisch-romischen Zeit, in Jervell, J \& Meeks, WA (eds), God's Christ and his people: Studies in honour of Nils Alstrup Dahl, 18-28. Oslo: Universitetsforlaget.

DERRETT, JCM 1968. 'You built the tombs of prophets' (Lk 11: 47-51; Mt 23: 29-31), in Cross, FL (ed), Studia Evangelica IV, 187-193. Berlin: Akademie.

ENGELBRECHT, E 1985. Sending en geregtigheid in die Matteusevangelie. DD-proefskrif, Universiteit van Pretoria.

FOERSTER, W 1938. sv Kúrios. TWNT.

FRANKEMOLLE, H 1974. Jahwebund und Kirche Christi: Studien zur Form- und Traditions geschichte des 'Evangeliums' nach Matthäus. Münster: Aschendorf. 
GAECHTER, P 1963.Das Matthäus-Evangelium: Ein Kommentar. Innsbruch: Tyrolia.

GASTON, L 1975. The Messiah of Israel as teacher of the gentiles. Interp. 29, 24-40.

GERHARDSSON, B 1973. Gottes Sohn als Diener Gottes: Messias, Agape und Himmelherrschaft nach dem Matthäusevangelium. StTh 27, 73-106.

GERHARDSSON, B 1979. The mighty acts of Jesus according to Matthew. Transl by Dewsnap, R. Lund: CWK Gleerup.

GIBBS, JM 1968. The Son of God as the Torah Incarnate in Matthew, in Cross, FL (ed), Studia Evangelica IV, 38-46. Berlin: Akademie.

GNILKA, J 1986. Das Matthäusevangelium, 1. Teil: Kommentar zu Kap 1, 1-13, 58. Freiburg: Herder. (HThK.)

GUNDRY, RH 1982. Matthew: A commentary on his literary and theological art. Michigan: Eerdmans.

HAHN, F 1974. Christologische Hoheitstitel: Ihre Geschichte im frühen Christentum. 4. Aufl. Göttingen: Vandenhoeck.

HARRINGTON, DJ 1975. Matthean studies since Joachim Rhode. Hey] 16, 375-388.

HENGEL, M 1976. The Son of God: The origin of christology and the history of lewishHellenistic religion. Transl by Bowden, J. Philadelphia: Fortress.

HIGGINS, AJB 1980. The Son of man in the teaching of Jesus. Cambridge: Cambridge University Press.

HILL, D 1972. The Gospel of Matthew. London: Oliphants. (NCeB.)

HILL, D 1980a. Son and servant: An essay on Matthean christology. JSNT 6, 2-16.

HILL, D 1980b. Oorsigartikel: Nolan, BM 1979. The royal Son of God: The christology of Matthew 1-2 in the setting of the Gospel. Göttingen: Vandenhoeck. JSNT 9, 66-69.

HILL, D 1984. The figure of Jesus in Matthew's story: A response to Professor Kingsbury's literary-critical probe. JSNT 21, 37-52.

HOH, J 1926. Der christliche grammateús. BZ 17, 256-269.

HULTGREN, AJ 1979. Jesus and his adversaries: The form and function of the conflict stories in the synoptic tradition. Minneapolis: Augsburg.

HURTADO, LW 1979. New Testament christology: A critique of Bousset's influence. TS 40, 306-317.

HUMMEL, R 1966. Die Auseinandersetzung zwischen Kirche und Judentum im Matthäusevangelium. München: Kaiser.

JEREMIAS, J 1971. Neutestamentliche Theologie, I: Die Verkündigung Jesu. Güthersloh: Mohr.

JONES, DL 1979. Oorsigartikel: Hengel, M, The origin of christology and the history of Jewish-Hellenistic religion. Interp. 33, 424-430.

KAMPHAUS, F 1971. Zwischen Abfall und Nachfolge: Auslegung und Besinnung zu Mt 16, 21-28. BiLe 12, 48-54.

KEALY, SP. 1979. The modern approach to Matthew. BTB 9, 165-178.

KECK, LE 1980. Jesus in New Testament christology. ABR 28, 1-20.

KELBER, WH 1979. Redaction criticism: On the nature and exposition of the gospels. Perspectives in Religious Studies 6, 4-16.

KINGSBURY, JD 1975a. Matthew: Structure, christology and kingdom. Philadelphia: Fortress.

KINGSBURY, JD 1975b. The title 'Kyrios' in Matthew's gospel. JBL 94, 246-255.

KINGSBURY, JD 1975c. The title 'Son of man' in Matthew's gospel. CBQ 37, 193-202.

KINGSBURY, JD 1977. Matthew. Philadelphia: Fortress. (Proclamation Coommentaries.)

KINGSBURY, JD 1978. The verb AKOLOUTHEIN ('to follow') as an index of Matthew's view of his community. JBL 97, 56-75.

KINGSBURY, JD 1984. The figure of Jesus in Matthew's story: A literary-critical probe. JSNT 21, 3-36.

KINGSBURY, JD 1985. The figure of Jesus in Matthew's story: A rejoinder to David Hill. JSNT 25, 61-81. 
KINGSBURY, JD 1986. Matthew as story. Philadelphia: Fortress.

KLOSTERMANN, E 1971. Das Matthäusevangelium. 4. Aufl. Tübingen: Mohr (HNT.)

KÜMMEL, WG 1980. Jesusforschung seit 1965. ThR 45, 40-84.

LANGE, J 1973. Das Erscheinen des Auferstandenen im Evangelium nach Matthäus. Würzburg: Echter.

MEIER, JP 1979. The vision of Matthew: Christ, church and morality in the first gospel. New York: Paulist.

MEIER, JP 1980. Matthew. Wilmington: Glazier. (New Testament Message.)

MONTEFIORE, H 1964/5. Jesus and the temple tax. NTS 11, 60-71.

MOWINCKEL, S 1956. He that cometh. Oxford: Oxford University Press.

NOLAN, BM 1979. The royal Son of God: The christology of Matthew 1-2 in the setting of the Gospel. Göttingen: Vandenhoeck.

PESCH, R 1967. Der Gottessohn im matthäischen Evangelienprolog (Mt 1-2): Beobachtungen zu den Zitationsformeln der Reflexionszitate. Biblica 48, 395-420.

PETERSEN, NR 1978. 'Point of view' in Mark's narrative. Semeia 12, 97-121.

POKORNÝ, P 1971. Der Gottessohn: Literarische Übersicht und Fragestellung. Zürich: Theologische Verlag.

PRZYBYLSKI, B 1980. Righteousness in Matthew and his world of thought. Cambridge: Cambridge University Press.

ROGERS, C 1973. The great commission. Bibliotheca Sacra 130, 252-267.

RHODE, J [1966]. Die redaktionsgeschichtliche Methode: Einführung und Sichtung des Forschungsstandes. [Hamburg]: Fürche.

SAND, A 1974. Das Gesetz und die Propheten: Untersuchungen zur Theologie des Evangeliums nach Matthäus. Regensburg; Pustet.

SCHLATTER, A 1963. Der Evangelist Matthäus. Seine Sprache, seine Ziel, seine Selbeständigkeit: Ein Kommentar zum ersten Evangelium. 6. Aufl. Stuttgart: Calwer.

SCHMID, J 1965. Das Evangelium nach Matthäus. 5. Aufl. Regensburg: Pustet. (RNT.)

SCHNIEWIND, J 1968. Das Evangelium nach Matthäus. Göttingen: Vandenhoeck. (NTD.)

STRECKER, G 1966. Der Weg der Gerechtigkeit: Untersuchung zur Theologie des Matthäus. 2. Aufl. Göttingen: Vandenhoeck.

SUHL, A 1968. Der Davidssohn im Matthäus-Evangelium. ZNW 59, 57-81.

TATUM, WB 1981. Oorsigartikel: Nolan, BM, The royal Son of God: The christology of Matthew 1-2 in the setting of the Gospel. JBL 100, 125-127.

TODT, HE 1959. Der Menschensohn in der synoptischen Überlieferung. Gütersloh: Mohn.

TRILLING, W 1964. Das wahre Israel: Studien zur Theologie des Matthäus-Evangeliums. 3. Aufl. München: Kösel.

USPENSKI, B 1973. A poetics of composition: The structure of the artistic text and typology of a compositional form. Transl by Zavarin, V \& Wittig, S. Berkeley: University of California Press.

VAN AARDE, AG 1982a. God met ons: Dié teologiese perspektief van die Matteusevangelie. DD-proefskrif, Universiteit van Pretoria.

VAN AARDE, AG 1982b. Matthew's portrayal of the disciples and the structure of Mt 13: 53-17: 27. Neotestamentica 16, 21-34.

VAN AARDE, AG 1985. Vertellersperspektief en die 'temporele' funksie van die Ou Testament in die Matteusevangelie. HTS 41, 272-189.

VAN AARDE, AG 1986a. Plot as mediated through point of view: Mt 22: 1-14-A case study, in Petzer, JH \& Hartin, P (eds), A South African perspective on the New Testament: Essays by South African scholars presented to Bruce Manning Metzger during his visit to South Africa in 1985, 62-75. Leiden: Brill.

VAN AARDE, AG 1986b. Proefskrifbespreking: Engelbrecht, E, 1985. Sending en geregtigheid in die Matteusevangelie. HTS 42, 170-176.

VAN IERSEL, BMF 1964. 'Der Sohn' in den synoptischen Jesusworten: Christusbezeichnung der Gemeinde oder Selbstbezeichnung Jesu? 2. Aufl. Leiden: Brill. 
VERMES, G 1973. Jesus the Jew: A historian's reading of the gospels. London: Collins.

VERMES, G 1978. The 'Son of man' debate. JSNT 4, 58-68.

VIA, DO 1980. Structure, christology, and ethics in Matthew, in Spencer, RA (ed), Orientation by disorientation: Studies in literary criticism and biblical literary criticism. Presented in honor of William A Beardslee, 198-215. Pittsburg: Pickwick.

VÖGTLE, A 1964. Das christologische und ekklesiologische Anliegen von Mt 28, 18-20. SE 2, 266-294.

WALKER, R 1967. Die Heilsgeschichte im ersten Evangelium. Göttingen: Vandenhoeck.

WREGE, H-T 1978. Die Gestalt des Evangeliums: Aufbau und Struktur der Synoptiker sowie der Apostelgeschichte. Frankfurt a M: Peter Lang.

YARNOLD, E 1968. Teleios in St Matthew's gospel, in Cross, FL (ed), Studia Evangelica IV, 269-273. Berlin: Akademie. 